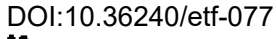 \\ ERDÉLYI TUDOMÁNYOS FÜZETEK
}

EME

DR. GYÖRGY LAJOS

\section{JÓKAI}

ROMÁN TÁRGYÚ NOVELLÁI

\author{
IRTA , \\ Dr. RAJKa LÁszLó
}

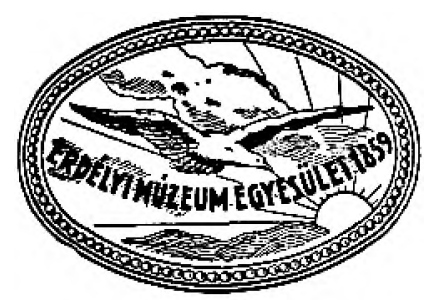


1848-49 lázas eseményei után Jókai egyelöre pihenni kényszerültt. A még alig huszonötéves ifjú azonban természeténél fogva sem lett volna képes arra, hogy napjait tompa kétségbeesésben, tétlenuil töltse el. Alig volt a nagy író életében korszak, amelyben többet tanult volna, mint az 1850-es évek elején, amikor a szuiletett müvész határozott ösztönével figyelte meg a magyar nép faji sajátságait, épúgy a vele együttlakô többi népekét is; amikor hozzálátott a vándorló tréfák és anekdoták összegyijjtéséhez; és mindezek mellett nagyszabású történelmi tanulmányokat végzett, sokkal szélesebbkörüeket és alaposabbakat, mint ahogyan azt az eddigi kutatás általában föltételezte. Érdekesen bukkannak elönkbe Jókai tanulmányai munkáinak tükrében: 1851-tŏl kezdve sorra jönnek: Cserei, Gibbon, a nagy francia anekdota-gyüjtemény, Bethlen János, majd Hammer-Purgstall óriási méretü török történelme és az akkor frissen megjelent Poujoulat-fóle török történelem német fordítása. Ez esupán szerény választék, mert egészen biztosan jóval nagyobb az anyag, amelyet Jókai alig nehány év alatt nemcsupán fölületesen, hanem sokszor meglepö alapossággal átkutatott. Egyik-másik münek a terjedelme is óriási; így Gibbon, vagy pedig Hammer-Purgstall figyelmes átolvasása önmagában is nagy munkát kívân. Mi fordította Jókai figyelmét épen ebbe az iránybà Ennek magyarázata talán nem nagyon nehéz. A szabadsághare után sok magyar menekült külföldðre; a menekülés útja pedig csupán Törökország felé volt nyitva s ez az ország ebben az idoöben még közvetlenül határos volt Magyarországgal. Törökországban régi hagyomány paranesolta a menekuiltek felkarolását: Kossuth ês társai szíves vendégszeretetre találtak. Lassanként hírek érkeztek a kibujdosottaktól, életiik olyan szoros kapesolatban állott e bomladozó birodalom belviszonyaival, hogy az érdeklödést a török szokások és erkölesök, történelem és nyelv iránt önkéntelenül is felkeltették. A magyar nábobban Kecskerey a kor divatjának hódol, amikor török inast tart és vele törökül beszél. Jókai romantikus képzeletét módfelett izgatta a rejtélyes Kelet. Az âltalános érdeklödést még fokozta az 1853 ban kitört orosz-török háború, amelyben esaknem egész Európa a törökök pártját fogta. Mennyivel melegebb érdeklöđésre számíthatott a törökök ïgye a magyaroknál, akik amúgyis gyứlölettel és fájdalommal gondoltak szabadságuk eltiprójára, a törökökkel szemben állố oroszra. A török események azonban szoros 
kapesolatban állottak az ott élö keresztény népek történetével, hiszen Tơrökország alkkor még - legalább is papiron - magában foglalta a Román Fejedelemségeket és Szerbiát is, a mai Bulgária pedig tökéletesen be volt kebelezve az akkor még óriási terjedelmí birodalomba. A török történelem tanulmányozása egyet jelentett a román, szerb, bulgár és görög történelem fởbb mozzanatainak ismeretével. Innen indul ki Jókai érdeklódése a román nép iránt, ebben az idöben ismerte meg a Román Fejedelemségek történetének egyik fejezetút, amelyet azután ismételten fellasznált román tárgyú novelláina.k keretéijl.

Jókai első román tárgyú novellája az 1853-i orosz-törờ háborúról írott könyvében jelent meg $A$ bojar-leány ${ }^{1}$ címen 1855 -ben. A bevezetöben ismertetett vonásokat jellemzóen igazolja.

Küriáki Sándor Havasalföldön lakott, ahol elökelö fốúr, bojár volt. Réaztrett 1825-ben a hetêria kuzzdeimeiben. Az ó testvére adta ki magát Jurdaki helyet a kolostorban, mire lefejezték. A fejét megváltotta és eltemette. A felkelés szerencsétlen vége után elyonult a világtól. Hat fja volt és egy leánya: Neszle. 185ś-ban azzal jöttek hozzá fiai, hogy nagy hadjáratot indított az orosz a török ellen, ittött a bosszú órája. Frre az ósz Kiuriáki azt hitte, hogy itt a hare, mely a román népet felszabadítja s olyan urrá teszi ismét apái földén, amilyen volt a nagy Bazarad alatt" örömmel üđoözölte az oroszokat, gazdagon megvendégelte óket és fiait harcra késztette. A lakoma alkalmával Neszto hárfakíséret mellet $t$ elénekelte a szép Lienka regéjét. Ez arról szólt, hogy a várnai ätközetbe ment a magyar király, Hunyadi János és Drakul vajda. Ennek leánya volt Lienka, aki a király mellett lovagolt és vele együtt eset el.

A nagy lelkesedésben Neszte felajánlotta, hogy kémkedui fog az ellenfó] táborában. Minthogy anyja lengyel nơ volt, ó maga is kitünỏen tudott lengyeliil és kiadta magát menekült lengyelnek. Tisztnek öltözve atkelt a Dunńn egy lélekvesztón és kikémlelte a törökök állásait.

Egy napon Giurginban ${ }^{2}$ idózött a szép Neszte egy kávéházban több tiszt társaságában. Egyszerro lármát hallottak, egy embert vittek vesztení. Egy csolnakos volt; a törökök ugyanis minden esolnakot összeszedtek, hogy a kémkedést megakadályozzák. Nesztét egy tiszt karonfogta és kényszerítette, hogy jojjjön el a látványosságra. Neszte azonnal megismerte, hogy ez az ó csolnakosa, akit bizonyára utána külddöttek. Az utolsó pillanatban az ember ráismert és Nesztére mutatott. Nesate azonban kihasználta a pillanatnyi zavart és azt állította, loggy az öt karonfogó tiszt a kém. Nehány perce aiatt a Dula partjára sietet és a vízbe vetette magát. Bár üldöztêk, megmenekült es elérte a túlsó partot, ahol elájult. Itt a kozákok megismerték. hogy leány és erószakosk val lelötte és megmenekäilt. Nagy fáradalmak után hazaért, s megdöbbenve lätta, hogy kastélyuk rom. Egy öreg jobbágy sirva mesélte el, hogy az oroszok összevesztek Küziákival és egész osalédját lemészárolták, kastélyát pedig felgyújtotlálk. Az orasz tábornok semmit sem tudott a Küriáki család veaztéról. Igy Neszte felkereste és behatóan tájékoztatta, hogy milyen az ellenfól allása. Ez a tájékoztatás azonban félrevezetés volt. Az oroszơ a hamis adatok alapján megvivtál az siteníczai iitközetet és borzasztó vereséget szenvedtek. Küriáki leánya pedig kolostorba vonalt.

1 Jókai Mor: Veres könyv. Elöször megjelent három kötetben Pesten 1855-ben. A Nemzeti Kiadásban: Véres könyv. Csataképeh a keleti haborúból. Bp. 1894. A Nemzeti Kiadás XIX. kötete. A novella ez utóbbi kötet 268-288. lapjain található.

'Jókainál: Dsurdsa. 
Eza a novella jellemzöen mutatja Jókai felfogását és tárgyi ismereteit a román viszonyokról. Amit itt téved, az végig kísérte összes hasonló körböl vett novelláiban; amit a románokról elképzelt vagy clgondolt, azt késóbb is hüségesen megismételte. Jókai voltaképen egy jelentős román történelmi eseményt ismert: Y psilanti fellelését és ezzel kapcsolatban Tudor Vladimirescu forradalmi mozgalmát. Ezt emlegeti is mindjárt novellája elején, de az évet nem jegyezte meg jól magának - meglátjul, hogy ez a hibája ismételten visszatér - és ágy vélekedett, hogy ezek a mozgalmas események 1825-ben történtek. ${ }^{3}$ Jókai további múködése szempontjából igen érdekes, hogy már itt említi Jordaki szerepét, hősi halálát egy kolostorban, szôval a hetéria mozgalmának egyil leggyászosabb eseményét.

Másik érdekes felfogásbeli tévedése Jókainak szereplöi nemzetiségében rejlik. Ugy hiszem, hogy Jókait nagy zavarba lehetett volna hozni, ha valaki e novejla megírásának idejejben megkérdezte volna tỏle, hogy miként kerülnek a gớögök a Román Fejedelemségekbe. Igy például itt is novellájának hơsét Küriákinak hívják. A hat fiú neve: Iuon, Pavlo, Sándor, Leo, Euthym és Péró. Hogy ezek jórészt nem hangzanak valami románosan, az Jókainak szemmel láthatólag nem tủnt fel. Jókait az tévesztette meg, hogy a román történelemben szerepet vívö férfiak között tömegesen talált ilyen neveket: Cantacuzeno, Ypsilanti, Gbica, Maurocordato, Brâneoveanu, stb. Minthogy a román tờrténelmet nem ismerte alaposabban, ezen úgy segített, hogy a fanariótákat megtette fanatikus román hazafiaknak. Ez még csak megjárja az 1850-es éveliben, amikor a görög arisztokrácia valóban lelkes románná alakult, de aligha volt helyén a század elején.

Van azonban Jókai novellájának más érdekessége is. Már itt felbukkan a jele, hogy Jókai ismerte a román népköltészetet. Az a románc, melyet Neszte ebéd alatt Szép Lienkácól énekel, feltúnően basonlít e kor román irodalmának népies haygú elbeszélö kởlteményeihez, amilyeneket küuönösen Aleesandri egykorủ költeményei között olvashatınk. A törökök clöl a Dunán átúszá és így menekülü leány alakja pedig a román népköltészet egyik legjellegzetesebb jelensége. Aleesandri híres népköltészeti gyüjteményében, ${ }^{4}$ amely elöszörr isó2-ben, tohât három évvel Jókai novellája elött jelent meg, olvashatjuk a Kira címü költeményt, melyben egy román leányt, Kírát, elrabol a török és Brailánál átviszi egy esolnakon a Dunán. Kira bátyjai a csolnak után úsznak és megmentik a leányt. Minthogy azonban azt hiszik, hogy Kira jószântából követte a törököt, ${ }^{5}$ a leányt máglyán megégetik, bármennyire esküdözik is, bogy ártatlan. Hasonló tárgyú költeményt közöl Vulcanu nép-

* A helyes évszám: 1821.

* Poesii populare ale Romanilor. Adunate si intocmite de Vasile Ale. esandri. Bueuresci. Tipografia luerătorilor asociați. 12. Pasagiul Romăn. 12. MDCGCLXVI. - A Kira eímỉ költemény e kiadás 116-120. lapjain olvasható.

"A költemény a törökōt ,arab"-nak nevezi. 
költészeti gyüjteménye is. ${ }^{6}$ Ebben Monka Belgrádban lakik. Itt fogják el a törökök A leány útközben a Drunába ugrik és úszva megmenekül a törököktöl. Ez így egymagában még gyenge bizonyíték lenne arra, hogy Jókai valóban ismerte a román népkoiltészetet, de a továbbiakban jóval nyomósabb érvekkel támogathatjuk állításunkat.

Jókai Bojár leány címúi novellája nem tartozik a kitünö romantikus jeles alkotásai közé. Nem tárgyi tévedéseiben rejlik gyengesége, hiszen Jókait e szempontból bírálni nem valami igazságos dolog; van ebben az elbeszélésben valami hideg feszesség, valami üres retorika, ami a mủalkotás becsét és élvezhetơségét lerontja. Azt roondhatnám, hogy az egészen olyan hangulat iil, mința Jókai maga sem hitt volna abban, amit leírt és állandón tudatában volt annals, hogy nem bisz elbeszélésének igazságában.

Emlitettem már, hogy Jókai a Bojar leány bevezetésében érdekes célzást tesz Jordaki esetére. Amit ott mond, az dióhéjban tartalmazza két évvel késöbb megjelent novellájának tárgyát. A Jordaki feje címủ novella az 1821-i Ypsilanti-fóle felkelés egyik érdekes mozzanatát örökíti meg.

A drăgăsani itközetben elhullott a hetéria szent serege Mindössze harminchárom ifjú menektilt meg Jjrdaki vezérlete alatt. Ezek magukkal hurcolták a szultán vejét. 'Tyndari béget és a zeki zárdéba menekültek. Az aṕtnó szivesen lătta ổket. A zárda termében loltan feküdt Jordaki nôvére, akinek vơlegénye, Mariotisz Naszta, az jfjak között volt. A törökök vezére, Girlet aga, ostrom alá veț́ a záreát. Tyundari bég még biztatta a toronyból, hogy esak ostromplja az ellenséget. Erre Jordaki lelötte ót. Girlet aga most köritlzárta az épületet és kiéheztette öket. Végsố szijkségükben elhatározták, hogy Jordaki leriegy a pfncébe és felgyưjitja a felhalmozott puskaport míg a többiek gyászialt énekelive. Ebbe mindnyájan beleegyeztek, esupán Mariotisz Naszta, a szép Iréne völegénye, ellenkezett, ó a többiek megretésére a törökök táborába ment és azt állította, bogy ö Jordaki. Az aga ngyanis a többieknek kegyelunet igért, ha vezérijket kiadják. Az aga pesesétes kegyelemlevelet állított $\mathrm{kj}$, de anłkor ebben bízva, elhagyták a kolostort, mindnyájukat negkötöztette. Az elfogott görögök csupán azt kérték az agától, hogy méo egvet énekelhessenek a kolostorban. Girlet aga ezt megengedte. Az ének felliangzott, Jordaki pedig, aki a piucében várakozott és a történtekról mitsem tudott, a levegóbe röpitette a zárdát. Két hónap mulva Jordaki elnyomorodva a szatambuli kórhazhan tért magához. Nem tudták, hogy ó Jordaki és szabadon boesátotíak. A nyomorék kiment az utcára. A szerály elótt egy kikjáltó keltelto fel figyelmét. A kikialtó nagy hangon hirdette, hogg itt látható a lázadó Jordaki feje. A fố a Mariotisz Nasztáé volt.

Az ember valósággal elszomorodik, ha a jơzan kutatás világánál kénytelen ráeszmélni arra, hogy ez a történet, legalább is ebben az alakban, a képzelet világába tartozik. A történelem Jordakija, az Ypsilantifelkelés leglellesebb vezére, a hetéria mozgalmának idején ötven éves

- Romón népdalok. Fordctottál Ember Györoy, Grozescu Julián, Vulcanu József, Bevezette Vulcanu Jozsef. Kiadja a Kisfaludy-Társaśag. Budapest, az Athenaeum Tulajdona. 1877. Az nonka eímúl költemény a kótet 8 -12، lapjain olvasható.

${ }^{7}$ Elöször megjelent a Szépirodalmi Közlöny 1857. évfolyamában. Másodszor a Dekameronban, 1858-ban. A Nemzeti Kiadásban a XI. kötet 193. lapján található. 
volt, nem pedig tizenhétéves ifjú. A Jókaitôl említett „zeki ${ }^{\star *}$ zárda voltaképen a Secul zárdát jelenti, abol Jordaki valóban hỏsi halált halt és nem menokült meg. A novellában említett többi név nem történelmi. ${ }^{\mathrm{g}}$

Hogy honnan meritette Jókai az elbeszélésének tárgyát, arra elég könnyü rájönni, ha ekkori munkásságát figyelemmel kísérjük. Jókai 1854-ben adta ki a Janicsárok végnapjai címủ regényét, ennek jegyzeteiben pedig ismételten hivatkozik az Augsburger Allgemeine Zeitung-ra. Minthogy a Janicsárok végnapjai címü regény elsösorban Ali janinai basa végsö kïzdelmeivel és bukásával foglalkozik, ez pedig 1820-1822-ben játszódott le, nagyon természetes, hogy Jókai az 1821. év eseményeit egy egykorú hírlapban, az Allgemeine Zeitung 1821. éfolyamában olvasta.

Az Allgemeine Zeitung, melyet megjelenési helyéröl neveztek augsburginak, konzervatív szellemil lap volt, amely mindenekelött Metternich reakeiós politikáját támogatta. Igy rossz szemmel nézte a görög szabadságharcot is, de kénytelen volt a vonatkozó híreket közölni. Jordaki 1821 július 14-ến bukkan fel benne elöször és innentöl kezdve hónapokon keresztül sürün szerepel. A lap beosztásánál fogva, minthogy a híreket országonként csoportosítva hozza, az akkori Román Fejedelemségek pedig Törökország kötelékébe tartoztak, a hetéria és Jordaki ügye a legszorosabban összekapesolódott a janinai basa küzdelmeivel. Igy Jókainak akarva-nem akarva, végìg kellett olvasnia Jordaki történetét is, amikor Ali basa életéhez keresett adatokat.

Az elsơ alkalommal (júl. 14.) arról értesüitünk, hogy a drăgăşani harctéren esupán Jordaki maradt hatvan emberével és ö fedezte a viszszavonulást. Késöbb azt halljuk, hogy a hetéria hívei a hegyekben bujdosnak. Egy esapat a slatinai kolostorba menekült (aug. 26.), itt a törốkök ostrom alá fogták öket. A török esapat vezetöje, a bim-basi megadásra szólitotta fel öket, de ezt ebben a pillanatban lelötték. A további hírek azután egészen közel visznek a novellában ismertetett eseményekhez, Jordaki és Farmaki a Seka kolostorba húzódtak mintegy háronaszáz hetéristával (szept. 20.) A kolostort szept. 17-én ostromolják a törökök, de egyelöre kevés sikerrel, mert ninesenek ảgyúik. Október 15-ên részletes tudósítást kapunk: Selihar bej ötezer emberével Niamz (Neamţu) környékén harmino göröggel ütközött össze. Ezek visszavo-

- Mindezt igen alaposan összefoglalta és a vonatkozó történelmi irodalomra is utalt Bítay Arpád, aki a novellát is lefordította Capul lui Iordache é́men a következó munka függelékében: Mauriciu Jókaï. Biografie si caracterizare cu prilejul aniversărí de o sută de ani dela nasterea lui. Din îneredintarea si en sprijinul Ministerului Artelor si at Cultelor de Dr. Gheorghe Kristóf, profesor de la literatura maghiara la Universitatea din Cluj. Ca adas: câtera nuvele caracteristice de alo lui Jókai. Traducere de: Dr. Arpád Bitay, profesor la liceul de fete "Marianum“ din Chuj. „Minerva“ Institut de Literatură §i Tipografie S. A. Cluj. (Megjelent 1925-ben.) A fordítás a kötet 119-124. lapjain. Jegyzet a 124-125. lapokon. Már Bitay is úgy vélekedik, hogy Jókaí valószínúleg valamilyen hírlapból meríthette tárayát.

A Janicsárol végnapjai és az Augsburger Allgemeine Zeitung közötti összefüggést tárgyalja Czunya Miklós Jókai töröktárgyu regényeinek forrdsairól cimú érteirezésében (Budapest, 1934), a 26-29. lapokon. 
nultak Sek kolostorba. Ez igen erős épiilet, erdős hegyek között. A görögök a falakon tïzelêssel védekeztek. Már napok óta folyik az ostrom eredmény nélkiil. A rákövetkezö napon a következố hỉrt olvassuk: A Piatra mellettj Ruhren kolostort a törökök bevették; csupán három hetérista menekült meg. A halottak közôtt van állítólag Jordaki is, aki igen hösiesen viselkedett.

Okt. 18-án: ${ }^{10}$ "Als Salisch Pascha von den fruchtenlosen Bemühungen der Türken gegen das Kloster Scek unterrichtet wurde, begab er sich selbst an der Spitze von 1000 Mann den 23. dalin. Den andern Morgen liess er die Griechen auffordern, sich zu ergeben, indem versichert wurde, es sollte kcinem etwas zu Leide goscheben, im Gegentheile jedem frei stehen, sich wohin er wolle zu legeben. Die Griechen, diesen Versicherangen trauend, öfneten die Thore, und legten die Waffen nieder; aber die Janitscharen fielen iber sio her und hieben sie zusammeri."

Okt. 19-én: "Den neuesten aus der Moldau einIaufenden Nachrichten zufolge war das feste Schloss Secku (unweit Nyamz), in welches sich die Uberreste der Insurgenten mit den beiden Kapitains, Jordaki und Farmaki, geworfen hatton, am 24. Sept. nach cinem hoftigen Bombadament von mehreren Tagen, von den türkisehen Truppen unter Salih Pascha's Kommando mit Sturm erobert, und alle darm befindlichen Insurgenten, meistens Albaneser, mit Ausnahme der beiden obgedachten Kapitaine, welche gefangen nach Konstantinopol geschikt wurden, niedergemacht worden."

Okt. 21-én az elozổ hírt megerösítik azzal a különbséggel, hogy Jordaki, nehogy az ellenség kezébe kerüljön, elégette magát. Még részletesebben értesülünk a következö számból: Jordaki beteg volt ús sebekkel borítva egy cellában találták. Most fegyvertársával, Farmakival egyuitt, Konstantinápolyban a legszörnyúbb halál elé néz. "Ihre Namen wird die Geschichte verewigen, und Europa ihnen ein gerechtes Mitleiden zollen..." Okt. 233-ín: Még megerôsítésre szorul Jordaki elfogatásának híre, minthogy a menekiiltek elboszéléso szerint három társával sikeruilt megszabadulnia. Eim Grieche, der sich im Kloster Seku edelmithig für ihn ausgab, soll dadurch seine Rettung moglich gemacht haben." $\mathrm{Ez}$ a hír még október 27-én is tartja magát: Jordaki sorsa móg mindig vitás. "Die Meisten behaupten, er sey gincklich gerettet." Mások viszont azt állítják hogy elégette magât feleségével és gyermekeivel együtt. A törökök két foglyot küldöttek Konstantinápolyba: az egyikröl azt állitják, hogy Jordaki, a másikról pedig, hogy Farmaki. Csak okt. 31-ến kapunk világosabb hît: most már bizonyos, hogy Jordaki a lấngok közótt lelte halálat. Betegen fekỉat a kolostor egyik cellájában, de - sejtve sorsát - szalmát és szurkot tétetet ágya mellé. Amikor a törökők közeledtek, sajátkeziileg felgyújtotta a cellát és így szenvedett bösi halált.

Dee. 7-én olvassul a dráma végét: „Aus der Moldau sind mehrere

${ }^{10}$ Eredeti belyesírással. 
von den bei der Binnahme des Schlosses Secku gefangenen Insurgenten hieher ${ }^{11}$ gebracht worden: Zweiunddreissig derselben wurden gestern Nachmittags in den verschiedenen Quartieren der Stadt and der Vorstädte, Kapitain Farmaki aber in der Hauptstrasse von Pera, enthauptet."

Jókai tehát mindent készen kapott. Csupán a mesteri bonyolítás az 00 nüve. Az anyag, a maga történelmi ellenmondásaival és valótlanságaival is, ott feküdt clötte. Jókai nem volt kritikai elme: ö egy anyaggal kapesolatban nem azt vizsgálta, hogy abban mi az igaz, hanem azt, hogy meseszövés szempontjából mi használható. Készen kínálkozott: a harminchárom ifjú, a békére felszólító török lelövése, a hósi önfeláldozás, a menekïlés, sơt - ami a száraz és rideg Augsburger Allgemeine Zeitung-nál a legnagyobb ritkaság - még a résztvevő, barátságos és lelkesiilt hang is. Jókai figyelmét rögtön fölkeltette a hálás anyag, amint azt két évvel elöbb kelit novellájának célzása világosan bizonyítja. Szokása szerint bizonyára jegyzeteket készített belöle és két év mulva megírta egyik leglendületeseßb, legszebb elbeszélését. Jókai novellája elbeszéléseinek heroikus esoportjába tartozik. Szokása volt neki a hósi bátorságot, a férfias elhatározást és a szabadságért folytatott küzdelmet prózai ôda formájában megörökíteni. Ezt tette itt is. Novellája költészetének maradandó kincseihez tartozik.

Jókait a törtónelem regényes mozzanatai mellett különösen érdêkelte a román nép. Másodilí erdélyi útján, 1858-ban, épen a románoktól lakott aranybánya-vidéket járta be ${ }^{12}$ és figyelmét különösen felkeltette a román nép életmódja, szokásai, mondái és általában mindaz, ami cgy nép sajătos belsö cletét alkotja. Idevágó regényei élénken bizonyítják meleg érdeklödését. Erdekes, hogy ebben az idöben két noveliát írt, amelyek a román néppel foglalkoznak. Mindkettö a Dekameronban jelent meg elöször, második erdélyi útjának évében.

Az egyik novella erdélyi tárgyú: Egy haramia-banda ä havason ${ }^{13}$

Fzelött ötven-hatvan esztendővel - természetesen a novella keletkezésének idejétöl szánlítva - Aradmegyét vakmeró szegónylegények nyugtalanították. 'Tizenketten voltak, vezérizket Gligornak hivták. A banda nevezetesebb tagjai voltak: Bunduka, egy hetven esztenuỏs ember, híres zárfelnyitó, azután a ,halszemin“" Ravasel. Arad akk ori alispánja elrendelte, hogy nem s7abad ennivalót jattatni a legényeknek. A pásztorokat is beparanesolta a hegyekből. Erre a bujdrssók egy napon megkötözve hozták magát Głigort az alispán kastólyába. Amikor azonban beléptek az alispánhoz, kényszerítették, hogy velük jöjjön barlangjokba. Itt kegyelmet kértek tóle, amit az alispán meg is ígért és kegyelemért fjlyamodott értük. Amíg az megérkezik, velük lakott az erdón és élelemmel látta el őket. Javulásuk bizonyságát adták azzal is, hogy cgy hozzájak állni szándékozó legényt megöltek. A kegyelem meg is érkezett; a Ievelet a pálosi óhitú pap olvasta fel nekik; ugyanott, a templomban tettek fogadalnat, hogy életủket megváltoztatják. Szavukat meg is tartották és mint tisztességes emberek haltak meg.

${ }_{12}$ T. i. Konstantinápolyba, ahonnan a tudósító nov. 10-éröl keltezve a hírt küldötte.

${ }_{12}$ Dr. Kristóf György: Jókai napjai Erdelyben. Pásztortiuzz kiadása. Minerva Irodalmi és Nyomdai Müint. R.-T. Cluj-Kolozsvár. 1925.

13 Megjelent a Dekameronban. Nemzeti Kiadás XI. kötetének 131. lapjától. 
Ennek az elbeszélésnek a tárgyát Jókai a pozsonyi Magyar Hirmondó címú lap 1784 . évfolyamából vette, ${ }^{14}$ de arról szemmel láthatólag nem volt tudomása, hogy ez a történet egy sokkal jelentösebb esemẻny elöjátéka volt, mint egy egyszerü rablótámadásé. A hegyekbe menekiilt emberck ugyanis elégedetlen román jobbágyok voltak, akik valóban magukkal hurcolták Forrai András aradi alispánt és annak közbenjárására kegyelmet nyertek. De az elégedetlenség azért tovább tartott és ugyanazon év öszén a Hora-Clossea felkelésben sokkal véresebb alakot öltött, mint a Jókai békés elbeszélésében. ${ }^{15}$

A Jókai engesztelékeny, összbangot keresô lelke különös örömmel csüggött ezen a jóságos tárgyon. A megtérö, megjavuló bünös, aki a társadalom hasznos tagja lesz, mindenben megfelelt nemcsak a romanticizmus szépért lelkesülö eszméjének, hanem a Jókai szeretetreméltó, szelid lelkíletének is. Nem csodálhatjuk tehát, hogy e tárgyat ugyanazon óvben némi helyszínváltoztatással megismételte. E novella címe: Reparált lelkek. ${ }^{16}$

A mult század végén" Moldvában nagyon bizonytalan világ volt, a sok háború tönkre tette a közbiztonságot. Végre a tilsití béke nyugalmat hozott, ugyanekkor egy igazságos fejedelem került trónra. A ronán népköltészet kïlönös szeretettel dicsó́ti a szegénylegényeket. Ezek az erdókben tanyáznak. a szegény nép pártfogói, búbájos tulajdonságokkal birnak. A fejedelemnek sok baja volt a bujdusó legényekkel. Végre úgy vetett véget a bizonytalanságnak, hogy felakaszatatott belơlük egy esapatot. Csupán a plojesti (I) hegyek között tartotta fenn magát egy hires vezér: „az erós Páva". Wzzel nem bírtak. Figy napon egy zzép cigányleány jelent meg a fejedelem elótt és felajánlotta, bogy elébe hozza Pávát. Azonban azt kérte a fejedelemtôl, hogy ne ölesse meg a legényt, hanem neki és társainak ajándékozzon egy puszta falut. A fejedelem menlevelet adstt, mely egy puszta falura szólott. A bübájos leány, Czittra, erre elvezette a legédyeket a faluba, ahol azok megtértek, bứnbắnatot tartottak a papok elött és megkeresztelkedtek. Páva neve Mihály lett, elvette Czittrát feleséguil és mint kovácsmester tisztességes élotet folytatott.

A novella ugyan a Román Fejedelemségekben játszik, - szemmel láthatólag nagyon bizonytalan történelmi és földrajzi keretek közitt, hiszen Ploieşti nem Moldovában van, körülötte ninesenek hegyek, stb. - de azért az elöbb tárgyalttal feltünö rokonságban van. Alapgondolata ennek is a bínös megtérése. Nagyon érdekes az elbeszélésben jól jellemzett román népköltészet. Jókai leírásából ugyanis világosan lehot látni, hogy ismerte a román népköltészet ama termékeit, melyeket "doina haiducească" névvel jelöl meg az irodalom. Ezek bujdosó szegénylegényekröl szólnak. ${ }^{18}$ Jókai erre vonatkozó adatait Alecsandri híres népköltési gyüjteményéböl merítette. Fibben olvassuk az ,erös Páva" kifejezésnek megfelelö "Păunul codrilor", vagy „Păunaşul codri-

1. Tolnai Vílmos: Jokai Mór forrásaihoz. Irodalontärtẻnet, 19z7. évf. 315. 1. A 62. lapon.

18 A Nemzetí Kíadás XII. kötetében a 208. laptól.

${ }^{17}$ T. i. a XVIII. század végén, mert Jókai elbeszélését a XIX. sz.-ban írta.

${ }^{1}$ Dr. Kántor Lajos: Magyarok a romón népköltészetben. Erdélyi Múzeum, 1939. 52. 1. 


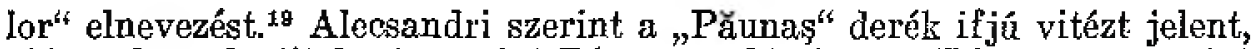
aki egyben oly titokzatos, mint Pán, az erdök istene. Véleménye szerint ennek emlékêt örzi e népmondai alak. Hî́res szegénylegényokröl több balladát közöl Alecsandri. Tlyen Vidra, vagy Bujor, aki a nép pártját fogta, épen ezért kedvelték és rejtegették. Ugyanitt értesülünk arrôl is, hogy egyes betyároknak megkegyelmeztek. Igy a Jianul címú balladához fưzôtt jegyzetböl' ${ }^{20}$ megtudjuk, hogy ez a híres betyár a XIX. század elején élt, kegyelmet kapott késöbb és békességben fejezte be életét Târgovisteben, ahol letelepedett.

Különös érdeklódésre tarthat számot az a kérdés, hogy honnan ismerto Jókai Aleesandri népköltési gyujteményét. Alecsandri múve a megjelenésének idején (1852) irodalmi esemény volt, melyet nemcsak a románság körében, hanem Európa-szerte ismertek és nagyra becsültek. Kotzebue Vilmos, a híres német drámaíró fia, akit esaládi kapesolatok és diplomáciai küldetések füztek a románokhoz, 1857-ben német fordításban adta ki Alessandri gyüjteményét. ${ }^{21}$ Elsô magyar ismertetöje, Acs $K$ ároly, szintén ebben az idöben müködött. ${ }^{22} \mathrm{Az}$ sem lehetetlen, hogy Jókai útközben, esetleg szóbeli küzlésböl ismerkedett meg az említett népköltési gyijjteménnyel. Bármikênt is áll a dolog, fényes bizonyítéka Jókai általános érdeklơdésének, amely különơs mohósággal kereste a népiesen jellemzó vonásokat.

A kêt népies román tárgyú novella megjelenése után Jókai huszonöt évig nem írt román tárgyú elbeszélést. 1883-ban jelent meg a Fejedelem és Fra Diavolo címú novellája. İ mégegyszer mintegy összefoglalja mindazokat a tárgyi ismereteket, amelyeket Jókai a románokról tudott. $^{23}$

A Fejedelem és Fra Diavolo címü novella a színészek világából meríti tárgyát. Páli uram színigazgató volt aki különösen operákat adott elö. Híres mósordarabja volt a Fra Diavolo. Pálì uram felesége énekelte a szopránt, Páli uram a tenort. Páli egyébként mereven játszott; kiálit a színpadra és hüvelykujjával malmozva enekelt vagy dikeiózott. Nyugodtsága is elárulta, hogy rendkívül jámbor ember volt. Az emlékezetes pozsonyi országgyúlés véget ért és a színésztársaság útra késziilt. Egy Avakum nevezetíi görög rábeszélte Pálit, hogy menjenek Bukarestbe. Egre-földre eskïdözött, hogy Bukarest szebb város, mint Bécs; hogy Kallimaki herceg teatrumot építetett, hogy az ủj fejedelem, János vajda, Párizsban tanult és lelkesedik a szinházért, \$ a felesége, Bajraktár nagy vezér leánya, török módra él. Van Bukarestben egy híres költob, Tarakszaki, az majd ellátja öket darabokkal. Addig-addig biztatta Pálit, míg végre útnak indultak.

10 Alecsandri idézett múvének 25. I.

to Alecsandri idézett múvének 160. 1.

${ }^{22}$ Rumänische Volkspoesie, Ber]in, 1857. - Vuleanut valami megtévesztette és úgy vélekedett, hogy Kotzebue múve elobbb jelent meg, mint az Alecsandrié. (Idézett munkájának bevezetésében a XXII, lapon.)

${ }^{3}$ Viragok a román népkóltészet mezejeról. Ismerteti és hiadja Acs Kóroly. Eisö́ fiuzet. Pest. Lauffer és Stolp bizománya, 1858 .

${ }_{23}$ Fejedelem és Fra Diavolo elóször megjelent a. Pesti Hirlap 1883. évi. 306. számában, másodszor az Athenaeum Nagy Képes Naptárának 1884. év. 1olyamában. A Nemzetí Kiadáa $\mathrm{LXIX.} \mathrm{kötetében} \mathrm{(Még} \mathrm{egy} \mathrm{csokrot)} \mathrm{a} \mathrm{116-}$ 147. lapokon 
Hosszú utazás utám végre megérkeztek Bukarestbe. A város csakugyan szép volt, a színészeket szivesen fogadták. Tarakszaki költố már másnap benutatkozott. Kis, púpos emberke volt s rögtön ajánlotta, hogy tanulják br hatfelvonásos drámáját, melynek a eíme: Milály vajda. Tanakszaki hevesen udvarolt a direktoménak, de esakhamar veszedelmes versenytársra talált János vajda személyében. A tárśsulat számtalanszor elóadta a Fra Diavolót. amelyet Taralszaki románra fordított. Közben nómi politikai nyugtalanság kezdódött, do Páli uram azzal mít sem föródött. Tarakszaki egyre unszolte a direktort, hogy adassa már eló a Mihály vajdát. Végủi egy este nagy hagymakoszornt dobtak a szinpadra. Ez az Unnahár fejedeiemasszony boszszúja volt, mivel megtudta, hogy férje a szép direktornénak vdvarol. Páli vram belátta, hogy ralamiképen vissza kell szereznie a közönség kegrét. Flóvették tehát Tarakszaki drámáját és ahogy todták, betanulták. Páli játszotta Mihály vajdát. Grie az alkalomra a fejedelem odakölcsönözte neki saját fejedelmi díszruháját, bajuszt ragasztott és világra úgy nézett ki. mint maga a fejedelem. Az elsỏ felvonás szerenesésen elindult. A színészek a román szöveget a sugó után szörnyú hibákkal tördelték, añín a közönség kitünóen mulatott.

Tarakszaki nem volt jelen. Ez a darab ugyanis esak jeladás volt a hetéria számára, melynek Tarakszaki is tagjai közé tartozott, hogy itt a felkelés pillanata. Gala felol érkezett a hetéria serege Wladimiresko Tivadar vezotése alatt. "Tervik az volt, hogy a fejedelmet elfogják és kéugszerítik, hogy vezesse obket a tôrökök ellen. A hetéria esakugyan elfoglalta Bukarestet. A rómhíre a fejedelem a Páliné öltözójébo meneküit. A direktorné feitalálta magát. Firtelen leborotválta a fejedelem bajusxát és Paij rabáiba bujtatta.

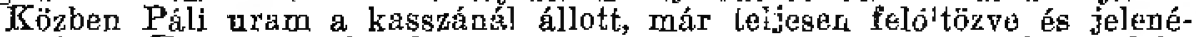
sére várva, Ggyszer esak odaront egy gyanos esoport, megragadta a fejedelem rahájába bujtatott direktort és a palota elé lurejlta. Itt óriási felfegyverzett tömeg várt reá. Mindenki azt hi1te, bogy go fejedelem. Felállított tik egy emelvéngre és azt követelték, hogy szónokoljon. Nem volt mit tenni: elszavalta a Mihaly vajda nagy jelenetét. Az pedig gyújtó szóninlat volt, umelyben felszólítja a Iépet, hogy vonuljon a töıökök ellen. Páli aram termé szotesen az egészból egy kuklot sem értett, csak azt látta, hogs szónoklata leírhatatlan viharos lelkosedést váltott ki. Utolsó mondata cz volit: "Most boesássatok a fejedelemnóhöz". Frre nagy diadalmenetbon cipelték a fejedelemnó lakosztályába. Unnahár fejedelemasszony, mint tórök nó, jól ismelte a ilyen zendüléseket. Egy eseppet sem jjedt mes. Elalota férje beszédet es szórnyói laragra gerjedt, hogy az a népet a törökök ellen tüzeli. Dühöen heszélt hozź. valamoi nyelven, amibỏl Páli uram semníf sem értett, csupán azt látta, hogy a fejedelemasszony selyemzsinórt, meg méregpoharat mutogat neki. Erre úgy megijedt, hogy kiszaladt. Odakint már várták. Lóra ültették, hogy vonuljanak az ellenség eilen.

A szinćszek a zendülés hírére hintelen összekapkodták a holmijukai és menekültek a határ felé. Vitték magukkal a fejedelmet is a direktor köntösében. Valami rlagy városiál helefutottak Ypsilanti táboríba. Ez is a fejedelem ellev vonalt, de a hetéria ellen is (1) az oroszok pátfogása alatt. Ypsilanti szívesen fogadta a színeszeket es azt ktvítuta, hogy játsszák el Fra Diavolót. Hiába magyarázták, hogy a Fra Diavolót megszemelyesító színész berekedt, Ypsilanti mindenfélo rekedtág elleni ortosságot itatott meng vele. Nem volt. más hátra: a fejedelemnek he kellett tanulnia Fra Diavoló szerepét. Az ám, de nem volt semmi hallása! Pálín rengeteget veszódót vele. Ypsilanti hix. telen színházat ácsoltatott össze és varatianul megjelent a probán. A megrémült fejedelem olyan lámpalázt kapott, hogy se nem látott, se nem ballott. Fkkox azonban hire étkezct, hogy ott a heteria serege Wladimireska vezetésével. N' erro Ypsilanti hirtelen elleñe vonult, a betériát leverte (II) ós Wladimireskót elfogta, Am János vajdát nem tudták elfogni. Páli uram

24 Hiven igyekszem visszaadni Jokai múvének tartalmát, hogy világosan bemutassam tơrtérelem-komponálo eljárását. 
ugyanis látva, hogy nagy a veszedelem, hirtelen leszedto az álbajusat, kibujt a fejedelmi köntösből és ellépett. Estére megkezdődött a Fra Diavolo elöadás. János fejedelem sehogysem akart fellépni. Páliné toporzékolt. Ekkวr a színpadról, ahol már folyt a darab, hirtelen felhangzott Fra Diavolo éneke. Páli uram ugyanig visszatalál társulatáhuz, gy orsan nekiöltözótt és kilépett a végszóra. Ennek hallatára Páliné a színpadra rohant és férje nyakába boralt, amiért Páli nagy hidegvérrel bïntetésre itćlte. Az elóadás azútán zavartalanal folyt, esak az egyik szerepló énekelt iszonyú hamisan. Az a fejedelem volt, aki még azon ejshalia Párizsba ment és suhasem tért tỏbbó visezu. Páli uram pedíg ünnepélyesen megtiltotta társulatának, hogy valaha egy szót is merjenek szólni a kalandjukról.

Jókai történelmi tévedéscit az elbeszélt események világosan câfolják. Nyilván láthałó, hogy Jókai olyan volt, mint a Bourbonok: nem tanult és nem felejtett semmit. 'Talán agész életében nem irt le nagrobb történelmi tévedést, mint amikor azt álította, hogy Y psilani leverte $a$ hetéria seregétl Fólösleges hangsúlyoznom, hogy epen Ypsilanti volt a hetéria fơvezére. De még bizonyos, érdekesobb részletek tấr gyalása elöt meg kell jegyeznem Jókai védelmére, hogy az Ypsilanti-Tudox Vladimiresou fejezet a Iorga német és francia nyelvü történelmi mưveinek megjelenéséig tókéletesen zavaros volt a külföldi történelmekben. Cantu Caesar, akit Jókai ebben az idóben olvasott, ${ }^{25}$ söt Oncken monumentális mưve is, mely Jókai könyvtárában megvolt, ugyanesak homályosan adják a vonatkozó részt. Példátlan ugyanis a történolemben, hogy ugyanazon helyen és ugyanazon idöben egyszerro három párt álljon egymással szemben. Kïlơnben Jókai múvei között ritkán luket találni még egy helyet, abol olyan szemmel láthatólag hangsulyozta volna a történelmi keret tökéletesen neliékes szorepét, mint itten. Is mégis mily sajátszerư - behatóbb történelmi vizsgálat után érdekes nyomokra fogunk bukkanni, amelyek a Jókai novellajának, ha förtémelmilgg nem is igazolják, de határozottan jelentóséget adnak.

A Jókai novellája mindenekelott érdekes kaposolatban van a román színészet kezdeteivel. Jelentéktelen kísérletektül eltekintve, a ronnán színjátszás azzal kezdớdik, hogy Caragea János fejedelem, aki bará sáa gos viszonyban volt Gentzcel, Metternich herceg títhárával, összeköitetése útján színészeket kért Bécsböl. Meg is érkezett 1818 augusztusảban egy Gherghy neví színigazgató társulatával, és drámai, valamint openaclóadásokat rendezett. ${ }^{26}$ Eza Gherghy, akinek nagy a fontossága a román szinészet megindításában, Gerger János brassói szász színigazgató volt, aki ebben az idóben nagy tevékenységet fejtett ki, többek kơzött Kolozsvárt is ismételten szerepelt. ${ }^{27}$ Világos, hogy a fejedolem leveléro Gentz az erdélyi kormányszékhez írhatott, hogy küldjenek színészeket

${ }^{25}$ Amint az Egy az Isten-hez füzött jegyzetei igazolják.

70 Teatrul la Román de Dimitrie $C$. Ollănescu, membru al Academiei Romane. Partea 11. Teatrul în Téra-Romanéscá. Bucuresci, 1898. 8. I.

${ }_{27}$ Ferenezi Zoltâll $A$ kolozsvári szinészet és salnház története. Kolozsvar, 1897. 254. 1. Hogy Gherghy valóban Gerger Jánossal azonos, kónnyen eldönthetö az Ollănescutól (a 8. lapon) említett Dilly-né nevú színésznố azonosságíval. Ez a színésznó ugyanis Dille-né néven szerepel Gerger színtársulatában. Mieg kell még említenem, hogy a románok ebben az idôben cirill betúkkel irtak, így a nevek átírása sokszor körïlményes volt. 
Bukarestbe. Ott pedig annál is inkább a Nagyszebenben és Brassóban tartózkodó Gergerre gondolhattak, mivel ez 1815 maajus 5-én Brassóban román nyelven elöadatta Kotzebue Die gefährliche Nachbarschaft cimü vígjátékắt. ${ }^{28}$

Gerger 1818 szeptember 8-án kezdette meg szereplését Bukarestben Rossini Olasz nö Algirban cimü operájával. A színi elöadások felkeltették az ebben az idôben a Román Fejedelemségekben tömörülö görög vezetökörök figyelmét. A hetéristák nem akartăk elmulasatani a kínálkozó jó alkalmat, hanem maguk is színtársulatot szerveztek, melynek célja a szabadságvágy felkeltése volt. Felváltva játszottak Gergerrel ugyanabban a helyiségben. Az elsö hetérista elödás - természetesen görög nyelven - Voltaire Brutus fiamal halala címú színmüve volt. Az elóadás oly lázba hozta a hetéría ifjú tagjait, hogy a színmü végeztével az uteán pisztolyaikat kilötték és forradalmi dalokat éneleltek. ${ }^{29}$ Ez volt a hetéria elsó nyilvános megmozdulása, de a felkelés csak 1821 elején tört ki. Valószinú, hogy Gerger Bukarestben egy olasz operatársasággal egyesült. Annyi legalábbis bizonyos, hogy egy számos tagból álló olasz operaegyíttes szerepelt Bukarestben, amikor az YpsilantiTudor Vladimireseu felkelés kitört ${ }^{30} \mathrm{Ez}$ a társasúg a zavarok elöl Brassóba jötł́ és itt 1821 május 3 -tól július 5-ig operaelöadásokat tartott ${ }^{31}$ Ugyanekkor sok elökelö bojár is Brassóba menekült, ahol a színi elöadásokat szemlélve, elhatároztâk, hogy maguk is buzgolkodni fognak odahaza a román színmúvészet érdekében. ${ }^{32}$ Nemesak az olasz társaság operaelöadásaiban gyönyörködhettek, hanem a magyar szinészek vendégjátékában is, akik 1822-ben és 1826-ban Brassóban vendégszerepeltek. ${ }^{33}$ 1826-ban Déryné is a tár'sulat tagjai közt volt és több bojárusaláddal ismerkedett meg; ${ }^{34}$ el is látogatott hozzájuk és velük folytatott társalgását szokott eredetiségével örökítette meg. Hgy Stefaneszlio nevút

20 Dr, Eugen von Filtsch: Geschichte des deutschen Theaters in Siebonbürgen. Arehi $\psi$ des Vereins für siebenbürgische Laudeshunde. Neue Folge.

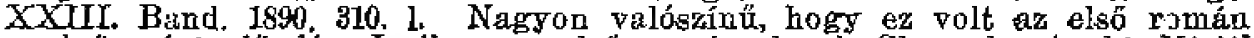
nyelvị színi elóadás. Iaşiban az elsó román darab Gheorghe Asaki Mirtil si Hloe cínă pásztorjátéka volt, melyet 1816 dec. 27 én adtak eló (Teodor T. Burada: Istoria teatrului in Moldova Iasi, 1915. 1. 99. 1.). Bukarestben 1819ben, vagy 1820 -ban adták Euripides $H e k u b a$ ómü drámájának román fordítását; ott ez volt az elsó román nyelven játszott darab (0ilăneseu i. m. 11. 1.). Tudva azonban hogy Gerger már azelött is notatott be román nyelven szindarabot, alig hỉhetơ, hogy Bukarestben már egy évvel elöbb ne jászott volna román nyelví színdarabokat. $\rightarrow$ A Kuetzebue eniitet vígátékápal egyiitt elóadtak d'Alayrae $W$ er Vieles bringt, wrd Jedem etwas bringen cimí operettjêt, de Filisch szövegezésében nem világos, hogy ez is román nyelven folyt-e. Meg keli még jegyeznem, hogy Filtsch nem ismerte a román szinészet tórténetét, Ollảnesca és Barada pedig Filtseh munkáját.

${ }^{29}$ Oilaneson i. m. 10-11. I.

* Ollănescu erröl nem tud. Filtsehnél 1. 313. I.

a Valószínulleg ezek adták eló az Oilănesentól (8. I.) emlitett operák jelentékeny részét. Ez ugyanis fényes társuság polt, elsórendú erókkel.

39 "Ollanescu, 16, 1.

Ferenczi Zoltán, i. m. 299. I.

* Déryné naploja. Sajtó alá rendezto Bayer József. Badapest. II. 257. 1. 
bojáresalád hivta Dérynét, hogy látogasson el Bukarestbe. 0 el is ment volna, de társai féltek a veszedelmes úttól. A román fönemesség olyan élénk érdeklödést mutatott a magyar szinészet iránt, hogy Ghica herceg, aki természetesen nem tudott nagyarul, tolmácesal haligatta végig az elöadásokat. Igy gyakran megtörtént, hogy egy- egy jobb kiszólás után az általános derültség teljes clesendesiultével kezdett a herceg nevetni, minthogy a tolmács akkorra fordította le a hallott szellemességet. ${ }^{35}$

Ha Déryné akkor elfogadja az ismételt szíves meghívást, ö vitto volna elöször a magyar színészetet Bukarestbe. Igy azonban ez a dicsöség Pály Fllek színigazgatót és híres magyar tonoristát illeti,ä aki 1840 október 18-án szerepelt döször Bukarestben ${ }^{37}$ Fetele de la Sziclosz címü darabbal romån nyelven. Valószínú, hogy ez a darab azonos Treitschke Siklósi borzasztó két ejszaka címú színmüvével, amelyet Komlóssy Fereno fordított magyarra és 1828 november 2-án mutattál be elöször Kolozsvárt. ${ }^{38}$ Pály csaknem egy hónapig idözött Bukarestben és Ghica Sándor fejedelem tiszteletére ünnepi elơdást rendezett ${ }^{39}$ hét élơképben, melyek a fejedelem áldásos müködését diesöitették.

A Jókai novellájában említett Fra Diavolo operát természetesen nem játszhatták a színészek Tudor Vladimiresou korában, tehát 1821-ben, minthogy Auber 1830-ban írta operáját és Bukarestben 1834-ben adták elöször. ${ }^{40}$

Érdekes a Jókaitól említett Tarakszaki név. 1599-ben ugyanis Vitéz Mihály vajdának egy latinul írt életrajza jelent meg, amelynek a szerzöje, Walther Baltazár, a mü elöszavában elmondja, hogy ezt az életrajzot eredetileg román nyelven írta a fejedelem kancellárja és egy lengyel, névszerint 'Taranoviu vagy Tarnovski (magyar helyesírással Tarnovszki) lengyel nyelvre fordította ${ }^{41}$ A név hasonlósága, továbbá az, hogy Tarakszaki épúgy, mint Tarnovszki Mihály vajdáról irnak, némileg gondolkozóba ejtheti az embert, bár valószinü, hogy csak a véletlen jảtékáról van szó.

Ts Déryné naploja, II. 264-265. 1.

an Született 1796-ban Pápán, meghalt 1846-ban Kolozsvárt. Szinrıeinél (Magyar Irók, X. 245-248. 1.) és a Színmúvészeti Lexikonban (III. 436-437. 1.) részletes életrajza, Ez ptóbbi Erö́di Jenótỏl.

${ }^{37}$ Szinnyei hibásan 1842-t ir. Ez az évszámtévedés Feleki Miklós életrajzából kerültt a Pály Elek adatai közé (Vasarnapi Ujság. 1877. 211. 1.) A Szinmúvészeti Lexikonban Erödi Imre a helyes érszámot írja, amely Ollăneseu idézet mưvének 103, lapjáról való. Nem tudtam megtalálni, hogy ki közölte magyarul a belyes adatot. Frö́di nem említi.

3 Ferenezi Zoltán, ì. m. 523. l.

39 Ollănescu szerint, ahonnan ezeket az adatokat vettem (103. 1.), a fejedelem trónrálépésének évfordulóján. De ez nem talál ’októberre, minthogy Ghica Sándor fejedelem 1834 áprilissában lépet trónra. Lehet azonban, hogy októberben iktatták be hivatalosan.

th Ollăneser i. m. 24. l.

"Gh. Adamesen: Istoria literaturii române. Bucuresti. Biblioteca pentru toti. 138-139. I. 
Jókai elbeszélésében valósággal elkábulva szemléljülk a valốság és képzelet kúsza szövedékét. Hiszen kétségtelen, hogy a Jókai novellája a legképtelenebb történelmi tévedések mellett a tờrténelem egészen elrejtett igazságait is magában foglalja. Ime: a hetéria első megmozdulása valóban egy szini elöadással volt kapcsolatos, a bukaresti szinészek valóban sietve menekültek a zavarok elöl Brassó felé és módfelett valószinü, hogy egyik-másik velük megbarátkozott bojár közéjüik keveredve, álöltözetben menekült ki az országból. Pály valóban adott román darabokat Bukarestben és a fejedelem tiszteletére hazafias játékot is rendezett.

Kétségtelen, hogy Jókai nem ilyen kínos adatgyüjtés nyomán jött elbeszélésének gondolatára. Felesége, Laborfalvy Róza, tanuja volt a magyar színészet hőskoránal és sok érdekes esetet mesélt el neki.42 Ebben az időben amúgy is nagy színészirodalmi esemény volt Déryné naplójának ismételt kơzlése.43 Valószínü, hogy Jókai a páratlan érłekességü naplót már kéziratban olvasta. Jórếszt innen került ki Pály jelleme. Ha együtt szerelmes szerepeket játszottak, - írja Déryné ${ }^{44}-$ Pály hidegen átkarolta és a páholyokon jártatta szemét, mialatt így énekelt:

\section{Ninette kedves lelek \\ Csupán te néked élek...}

Déryné erre megesípte figyelmeztetésüil, hogy hevesebben játssza a szerelmest, de Pály nyugodtan odasúgta neki: ma legalább háromszáz forint a jövedelem!

Pály második folesége, Botos Karolina, akiröI Jókainál szó lenne, jellemileg nem egyezik az elbeszélés szellemes, ügyes és találékony direktornéjával. Aligha járok messze az igazságtól, ha úgy vélekedem, hogy ez a Pálynó in kább a tüzrölpattant, páratlan ügyességú Déryné, akinek igy állitott emléket a nagy romantikus.

Ez a novella legélénkebb bizonysága annak, hogy Jókait nem Iehet csupán történelmi tévedései szempontjăból megbírálni. A $F$ rejedelem és Fra Diavolo Jókai legzseniálisab̉b elbeszélései közé tartozik. Nemesak a csapongó jókedv, a sokszor dévaj humor az, ami értékét kitünteti, hanem vígjátéki eselekvényének boszorkányos ügyességú bonyolítása, állandó és világos folyamatossága, amely lehetövé teszi, hogy állandóan át tudjuk tekinteni az egész szôvedéket. Ha Jókai müvei lassankint el is évälnek, ez a novella még sokáig fog dacolni a kérlelhetetlen idövel.

Vessünk még egy pillantást Jókai román tárgyú novelláira. Jókai voltaképen egy eseményt ismert a román történelemaböl, az Y psilantiTudor Vladimirescu-féle mozgalmat, amely 1821-ben játszódott le. Nem

49 Erre vonatkozólag érdekesen ír Jókai a Magyar Nábob bevezetésébeu a Nemzeti Kiadásban.

43 Elöször folytatásokban a Vasárnapi Ujság 1877. évfolyamában.

"Naploja. II. 311. 1. 
volt azonban pontosan tájékozva erröl sem, esupán egy-két fontosabb név és esemény maradt meg emlékezetében. A hiányzó részeket nem tanulmányokkal pótolta, hanem sajât képzoletéből egészítette ki, lugtöbbször az igazság rovására. Hasonlóképen gyengén ismerte a Román Fojedelemségek fơldrajzi viszonyait is. Inkább érdekelte Jókait maga a román nép, annak szokásai és loöltészete. Tanulmányozta az aklor megjelent híres Alecsandri-féle gyijjteményt és annak adatait felhasznála.

Jókai összes novelláit a román nép öszinte megbecsülése jellemzi. Bărhol is ír a románságról, mindig tísztességgol, sót szeretettel szól róluk. Román tárgyú novellái a romanticizmus hamisítatlan termélkei, amelyekben elsösorban a mese fontos, azután a népiessćg, s ezek mellett az adatok igazsága elhalványodik. Közöttük a Jordaki feje a heroikus, at Fejedelem és Fra Diavolo pedig a humoros nemben Jókai legkiválóbb alkotásui közó tartoznak. 


\title{
$\mathbf{A Z}$ \\ ERDÉLYI MÚZEUM
}

az Erdélyi Múzeum-Egyesület kiadásában jelenik meg évenként 12 számban, negyedévenként 6-7 ív terjedelemben. A folyóirat az E. M. E. Bölesészet-, nyelv- és történettudományi, 'Természettudományi-, Jogés Târsadalomtudományi Szakosztályának hivatalos közlönye.

\section{$\mathbf{A Z}$ \\ ERDÉLYI MÚZEUM}

az Egyesület alapító, igazgatósági és rendes tagjainak évi 300 lejes kedvezményes áron jár. Elọ̈fizetési ára nem tagoknak és Isönyvleres. kedöknek 400 lej. Elöfizetések és a lap szétkuildésére vonatkozó kívánságok címe:

\section{ERDÉLYI MÚZEUM kiadohivatala,} Cluj, Str. Baron L. Pop 5.

\author{
*ै \\ Magyarországi fóbizományos: STUDIUM R.-T. \\ Badapest, IV. Keeskeméti-u. 8. \\ Eliófizetési âra $12 \mathrm{P}$.
}

Kéziratok, ismertetésre szánt könyvek és a folyóirat szellemi részét illetỏ tudakozódások a szerkesztöt illetik:

DR. GYORGY LAJOS,

Cluj, Str. I. G. Duca 10.

A szerkesztöség közli az igen t. munkatărsakkal: 1. Géppel írott kéziratokat kér. 2. A kö̈zlésre szánt dolgozatok átlagos legnagyohb terjedelme 1 ív. 3. Minden munkatárs a folyóiratnak egyszersmind elöfizetöje is. A tiszteletdíjat 300 illetőleg 400 lejig a kiadóhivatal az elöfjzetés javára írja. 4. Külön-nyomat a szerzö kívánságára és költségére készuil. 5. A kéziratokat a szerkesztöség csak a szerzö külön kifejezett óhajára küldi vissza. 


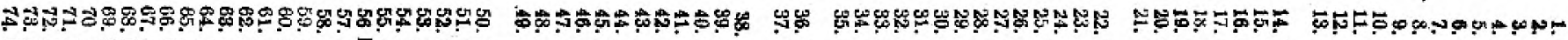

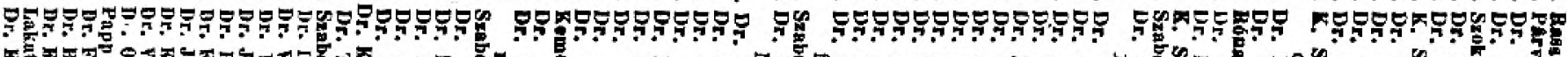

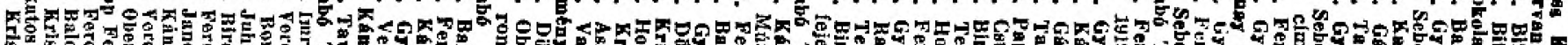

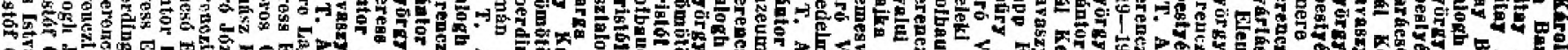
ONo

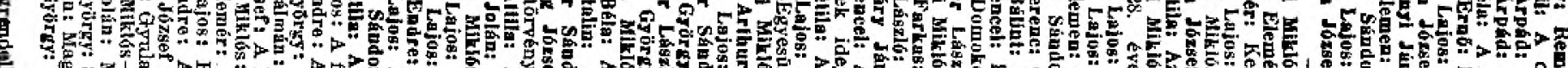
W

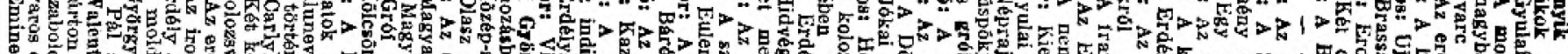
要 D

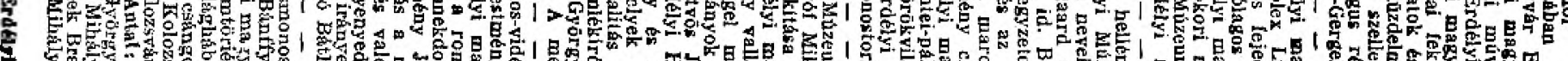
-

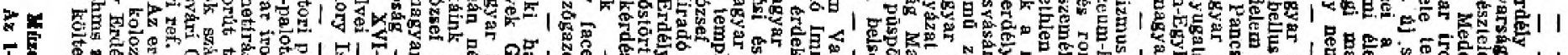

I

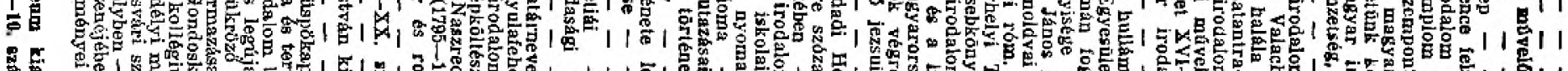

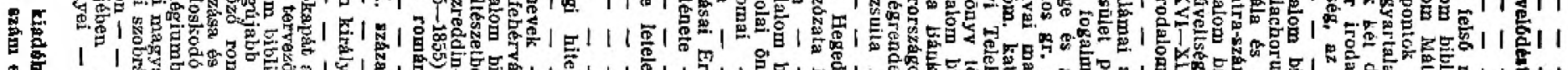

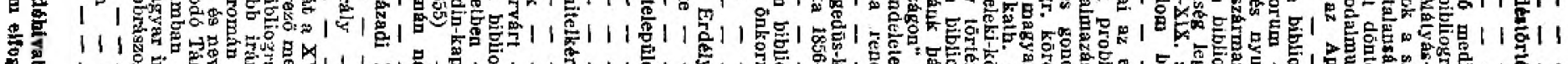

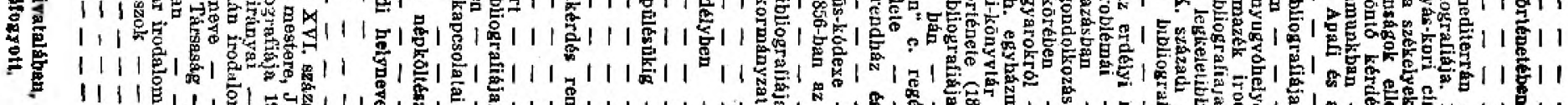

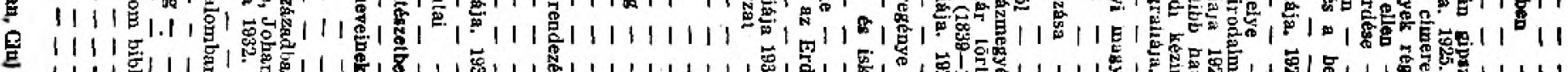

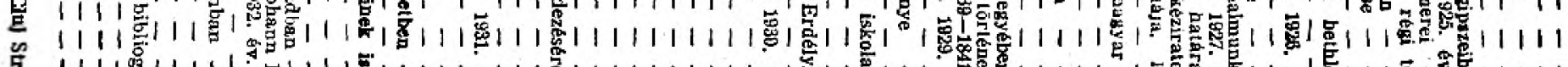

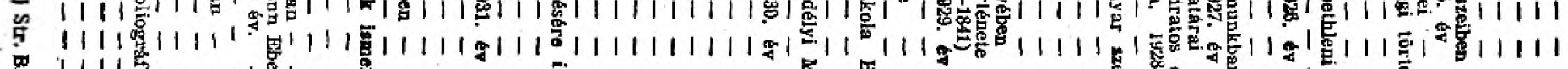

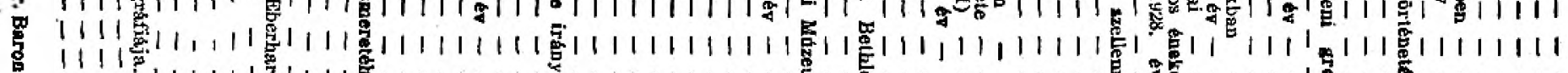

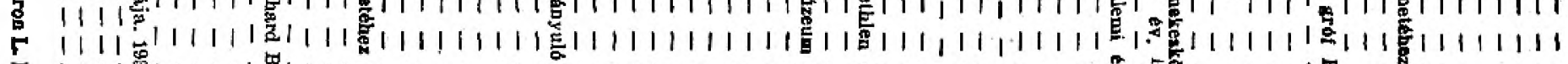

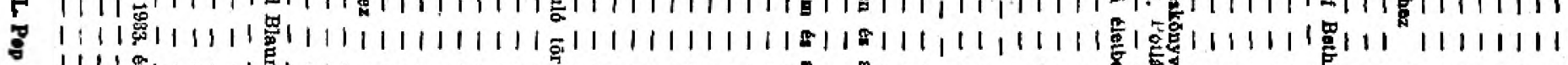

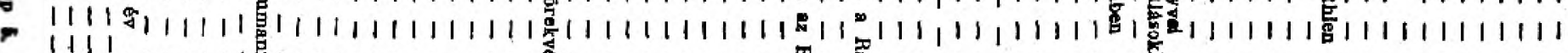
11111111111 111111111111兽11111111111

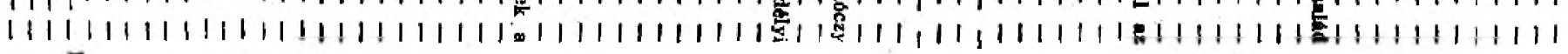

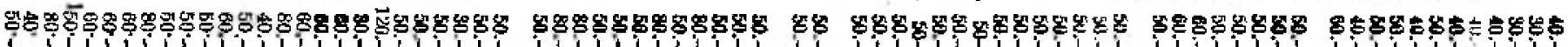

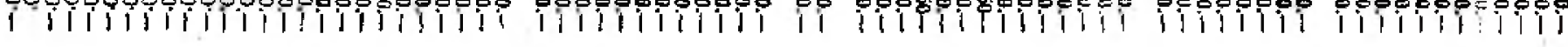

